\title{
ANNIE AND HER (M)OTHER IN A PARADISE LOST
}

\author{
ANNIE E SUA MÃE EM UM PARAÍSO PERDIDO
}

\section{Maria Aparecida de Oliveira ${ }^{1}$}

\begin{abstract}
In general, Jamaica Kincaid's fiction is a reflection on gender relations, sexuality, power and motherhood including the bonds between mothers and daughters, adults and children, men and women, colonizer and colonized. The aim of this paper is first to analyze the novel Annie John written by Jamaica Kincaid in 1985, bearing in mind the main character's relationship with her mother, with her motherland and with the colonial education imposed by the British Empire. Afterwards, the goal is to investigate the colonial discourse and its relation with the canon, by observing in which ways Kincaid subverts the imperialist discourse to develop her own sense of justice and injustice in a world of powerful and powerless.
\end{abstract}

Keywords: Mother and daughter relationship; colonizers and colonized; colonial discourse.

Resumo: Em geral, a ficção de Jamaica Kincaid é um reflexo das relações de gênero, sexualidade, poder e maternidade, incluindo os laços entre mães e filhas, adultos e crianças, homens e mulheres, colonizadores e colonizados. O objetivo desse artigo é inicialmente analisar o romance Annie John escrito pela autora Jamaica Kincaid em 1985, considerando a relação da personagem principal com a sua mãe, com a sua terra natal e com a educação colonial imposta pelo Império Britânico. Em seguida, pretende-se investigar o discurso colonial e sua relação com o cânone, observando de quais maneiras Kincaid subverte o discurso imperialista para desenvolver seu próprio senso de justiça e injustiça em um mundo dividido entre poderosos e impotentes.

Palavras-chave: Relação mãe e filha; colonizadores e colonizados; discurso colonial.

\section{Introduction}

Kincaid's work has been labeled as autobiographical, as she told in an interview, maybe they are based on the personal odyssey of a girl who began life as Elaine Potter Richardson in 1949 on the tiny island of Antigua, a girl who adored her tall, beautiful, intelligent Dominican mother, but who somehow lost that mother's love, a girl who left the Caribbean island to work as an au pair for an American family, and who, nurtured by anonymity and freedom of New York city in the 1970's reinvented herself as the writer Jamaica Kincaid. When asked to discuss the extent to which her work is autobiographical, she said "I started to write out of things. So I am driven to write, so it has to be autobiographical. I don't have any other reason to write. I am not interested in things for their own sake. I am only interested in explaining something for myself. At the same time, it is autobiographical it is also fiction. In the article "Jamaica Kincaid's New York" published in the Rolling Stone magazine, she said that reading Milton's Paradise Lost gave her the notion of what would become her own central theme, the relationship between the powerful and the powerless. It was a way of articulating her own pain, as Lucifer did, she felt as a child that she had been cast out of her own paradise. In what follows, it will be discussed the conflictive relationship between Annie and her mother, her motherland and the colonial education she was imposed to.

\footnotetext{
${ }^{1}$ Universidade Federal do Acre. Doutora em Estudos Literários. E-mail: mariaaoliv@yahoo.com; https://orcid.org/ 0000-0003-4815-7659; http://lattes.cnpq.br/2889350069897138
} 


\section{Annie and her (M)other}

J. Brooks Bouson (2005) notices that many critics always agree that Kincaid's troubled relationship with her mother is a metaphor of her troubled relationship with her motherland. The relationship between female characters and their mothers are always intermediated by intimations of life as colonized subjects, so that the cultural location becomes cruciall. Another critic says that the alienation from the mother becomes a metaphor for the young woman's alienation from an island culture that has been completely dominated by the imperialist power of England.

That is a clear connection between her hatred for her mother's domination and for England's power over Antigua. Perhaps, her hatred for her mother's control is also related to her fear of becoming dominated, once she refuses to become as subservient as her mother is to the colonizer's culture. However, at the same time her mother is subservient to the colonizer's culture; she is a powerful figure and can be very tyrannical sometimes, as we can read in her stories. Adrienne Rich, quoted by the author, reminds us that in Kincaid's fiction there is the process of matrophobia which is the fear of becoming one's mother and the complete identification with her. In order not to be double dominated she has to run away for both her mother and her motherland.

In Annie John the importance of the break between mother and daughter is industrial; all of a sudden the adored mother becomes distant, angry and critical, the daughter as a result is completely devastated, once her mother was considered to be her world and her inner conflicts are narrated then the reader gets to know her longing, her rage and the sense that the profundity of the loss has "erased" her. The break happens as the girl is approaching puberty, when she feels her body has been changed. The way Kincaid exaggerated the conflicts seems to be more than the usual trauma that puberty causes in mother and child:

I immediately said how much I loved this piece of cloth and how nice I thought it would look on us both, but my mother replied, "Oh no. You are getting too old for that. It's time you had your own clothes. You just cannot go around the rest of your life looking like a little me." To say that I felt the earth swept away from under me would not be going too far. It wasn't just what she said, but the way she said it. No accompanying little laugh. No bending over and kissing my little wet forehead (for suddenly I turned hot, then cold, and all my pores must have opened up, for fluids just flowed out of me). (KINCAID, 1985, p. 26)

Diane Simmons in her book Jamaica Kincaid refers to the way the psychologist Alice Miller explains this process between mother and daughter. She states that the narcissistic mothers are those whose sense of self is inadequate and requirements needing "someone at their disposal" who can be used as an echo, who can be controlled and offers full attention and admiration. But any move toward maturity or autonomy on the part of the child is experienced by the parent as a hostile act, even as an attack and the parent respond with a combination of hurt and anger. The mother's anger can be an expression that comes as a result that the object does not behave the way she expected or wished.

Her mother, as the colonizer, also wants to dominate, possess and control her daughter, whom by nature seems to be rebelling against any way of domination, who does not want to be killed in a suffocating embrace of love. So her mother ends up mocking the colonial educational systems, which seems to be inclined to erase all that is native, rewarding only which imitates the British rulers. Her mother wants to educate her as a young lady model of Englishness, instead of a rebel that she tends to become. Not only her mother, but also the teachers repeat the same constant colonial theme: ceaseless effort must be made to civilize the child, to turn her into a satisfactory imitation of a European young lady; this effort, though, can never be completely successful, due to the free and rebelling nature Annie possesses.

Keja Valens in Obvious and Ordinary: Desire between girls in Jamaica Kincaid's Annie John un-

https://periodicos.unifap.br/index.php/letras

Macapá, v. 9, n. 2, $2^{\circ}$ sem., 2019 
derstands the novel as a bildungsroman, a novel of coming of age, of discovery of self, which recounts the process of growing up and coming to terms with the world. Homi Bhabha describes this process as a kind of mimicry, in which the colonized subjects appear to perform according to the colonizer's ruling orders, but in fact revises those orders through repetition with a difference. When sent to learn to conform to a colonial model of femininity, Annie by not avoiding her desires, she is effectively resisting the imposition of colonial gender ideals:

Because of this young-lady business, instead of days spent in perfect harmony with my mother, I trailing in her footsteps and attention, I was now sent off to learn one thing and another. I was sent to someone who knew all about manners and how to meet and greet important people in the world. This woman asked me not to come again, since I could not resist making farting-like noises each time I had to practice a curtsy, it made the other girls laugh so. I was sent for piano lessons. The piano teacher, a shrivelled-up old spinster from Lancashire, England, soon asked me not to come back, since I seemed unable to resist eating from the bowl of plums she had placed on the piano purely for decoration. (KINCAID, 1985, p. 27)

Annie's ordinary acts work not only as a revolutionary reaction, but also as a revisionary resistance. Even in her community with other girls represent a control over her body and resistance to the colonial domination and grow up in this repressive system in which she would have to adapt. It is extremely important to emphasize that the household chores and the training to become a young lady is impossible, because she will never become a British young lady that would mean her complete erasure and the total acceptance of the other.

According to Valen, her relationship with the Red girl occupies a marginal space outside of social convention, offering Annie a path to the new, to the unknown, and to the forbidden. It is through the Red girl whom she admires, that she can participate in gender nonconformity and spatial transgressions that are unquestionably anticolonial:

What a beautiful thing I saw standing before me. Her face was big and round and red, like a moon - a red moon. She had big, broad, flat feet, and they were naked to the bare ground; her dress was dirty, the skirt and blouse tearing away from each other at one side; the red hair that I had first seen standing up on her head was matted and tangled; her hands were big and fat, and her fingernails held at least ten anthills of dirt under them. And on top of that, she had such an unbelievable, wonderful smell, as if she had never taken a bath in her whole life. (KINCAID, 1985, p. 57)

It is important to notice that the Red girl represents the return of the repressed, she is the extremely opposite of what Annie's mother does not want her to be. By doing that she is subverting the obvious and the ordinary coming of age in a colonial racist society.

H. Adlai Murdoch, in Severing the (M)other connection: the representation of cultural identity in Jamaica Kincaid's Annie John, states that one of the most intricate questions dealt by the Caribbean writer is that of identity. Murdoch interestingly calls the readers attention to the identity formation process of Antigua. Annie's mother is from Dominica, one of those territories whose history and culture is marked by extended possession and influence by the French, before being taken by the British Empire in 1783. The legacies of such colonial domination interfere in the persistence of cultural differences within the island chain, differences which most immediate result has been to perpetuate perceptions of intra-regional insularity, especially in the domains of language and racial appearance as markers of cultural identity.

Annie's mother is an omnipotent figure, a phallic mother who holds the power both in the family hierarchy in general and over her daughter in particular. This phallic construct goes hand in hand with the matriarchal family structure, valorizing the mother in the eyes of her daughter and generating the identification and authority, which she identifies and which she determines both her present and her future. Annie has to recognize herself as a subject and she has to search the truth of herself through the imagine of the (m)other, with whom she identifies. By 
this process of finding herself as a separate body, she has to build her way to become a real subject. The only problem is that the separation between them will be an inevitable and agonizing process.

\section{Annie and the Paradise Lost}

Annie's idea of her childhood as a kind of paradise is related to her connection with her mother and with her motherland; both of them represent an authentic part of herself which was not corrupted yet, as it is represented at the beginning of the novel:

Sometimes she might call out to me to go and get some thyme or basil or some other herb for her, for she grew all her herbs in little pots that she kept in a corner of our little garden. Sometimes when I gave her the herbs, she might stoop down and kiss me on my lips and then on my neck. It was in such a paradise that I lived. (KINCAID, 1985, p. 25)

The symbiotic relationship with her mother is described as a kind of Eden, a paradise. The way they are related and become one with nature and the natural relationship between their own one body and the sea:

The only way I could go into the water was if I was on my mother's back, my arms clasped tightly around her neck, and she would then swim around not too far from the shore. It was only then that I could forget how big the sea was, how far down the bottom could be, and how filled up it was with things that couldn't understand a nice hallo. When we swam around in this way, I would think how much we were like the pictures of sea mammals I had seen, my mother and I, naked, in the seawater, my mother sometimes singing to me a song in a French patois I did not yet understand, or sometimes not saying anything at all. I would place my ear against her neck, and it was as if I were listening to a giant shell, for all the sounds around me - the sea, the wind, the birds screeching - would seem as if they came from inside her, the way the sounds of the sea are in a seashell. (KINCAID, 1985, p. 43)

It is a very romanticized and exotified relationship. However, in her process of coming of age, she cannot have the same relationship with her mother and she gradually becomes aware of the islanders' subservience to the British, a status others seemed to accept as a common rule. As she becomes conscious of that and as she is naturally rebelling against the rules, once she avoids to be controlled by both her mother and the colonial educational system, she has to be cast out of this paradise. Annie's sense of survival is a result of the process which Said analyzes as "the self is faced with extinction by the very processes of acculturation which all who nurture the child commend. Only imitation and blind acquiescence are acceptable, not questioning gaze of an emerging intelligence."

Dianne Simmons in her book on Jamaica Kincaid devotes a whole chapter entitled Jamaica Kincaid and the canon: In dialogue with Paradise Lost and Jane Eyre. She says that the colonial education was an invitation to erase the colonized own culture and existence. However, Kincaid made sure to have a positive use of the English classics. Milton's Paradise lost taught her the sense of injustice and inspired her to express her own sense of what was right and what was wrong. Through her punishment of copying parts of the book, she was really attentive to the way Satan dealt with his crime and punishment. It was a story about powerful and powerless and in Annie's case she was really identified with Milton's anti-hero and the story helped her develop her own sense of control that is the relationship between powerful and powerless.

By subverting the canon, Kincaid explores her own predicament and creates her own version of paradise. Kincaid as a writer needs to use Milton's own creation myth, so that she can transgress history and transform the dominant discourse into her own. Annie's lost paradise is her childhood, a moment when she had the love of her mother and was in complete harmony with her motherland. However, her paradise becomes a hell, when she starts growing up and she realizes that her mother's love is not the same, but it turns to an obsessive control over her and 
with the obsessive training to transform her into a young lady.

The injustice and sufferings the character Annie John experiences can also be seen as a continuation found at the very heart of the British society, as Milton illustrates it. After losing her paradise, Annie needs to transform her hell into heaven, referring to Milton when he says "The mind is its own place and in itself/Can made a Heaven of hell, a Hell of heaven.” (2000, p. 9)

Her mother is sometimes expressed like a God figure, but on the other hand she is also oppressed by the racist and colonial authority. Annie's teachers, the representatives of colonial power are depicted as petty and ridiculous, they have no redeeming features, and they appear to be as soulless and physically unattractive. In her struggle to rebel against forces both at home and at school which both deny her true identity. But at the end she cannot bear the weight of her opposition and she falls into a long illness. It is only with the help of Ma Chess, her dear grandmother, who realized it was more of a spiritual illness than a physical one. After her rebirth, Annie is free to take her next step into a free life. Ma Chess re-mothers her.

Both her mother and the colonial educational system repress Annie's independence and individual identity. They reject Annie as she really is and they refuse any attempt to form her own identity. Her mother as seen before considers her daughter as an echo of herself and she does not want her to go out of her control and dominance. As well as the colonial system that does not regard the Antiguans as people with their own history, culture and identity. Besides they try to inculcate British values, which end up in the process of erasure of the native's local reality. It is sure that any child, as bright as Annie was, would suffer a damaging loss of identity and selfesteem and in order to build her own identity she could not find a better way, but leaving both her mother and her motherland.

\begin{abstract}
Pointing a finger at Ruth, Miss Edward asked a question the answer to which was "On the third of November 1493, a Sunday morning, Christopher Columbus discovered Dominica." Ruth, of course did not know the answer, as she did not know the answer to many questions about the West Indies. I could hardly blame her. Ruth had come all the way from England. Perhaps she did not want to be in the West Indies at all. Perhaps she wanted to be in England, where no one would remind her constantly of the terrible things her ancestors had done; perhaps she had felt even worse when her father was a missionary in Africa. I could see how Ruth felt from looking at her face. Her ancestors had been the masters, while ours had been the slaves. We could look everybody in the eye, for our ancestors had done nothing wrong except just sit somewhere, defenseless. Of course, sometimes, what with our teachers and our books, it was hard for us to tell on which side we really now belonged - with the masters or the slaves - for it was all history, it was all in the past, and everybody behaved differently now; all of us celebrated Queen Victoria's birthday, even though she had been dead a long time. But we, the descendants of slaves, knew quite well what had really happened. (KINCAID, 1985, p. 76)
\end{abstract}

It cannot be forgotten that the colonial educational system emphasizes European History and culture, especially British history and literature, while their own culture and literature was erased and forgotten. Children were forced to learn their own history through a British colonial perspective. They had to glorify Christopher Columbus as a great man, once he was the founder of their island, ignoring the fact that their ancestors became slaves due to Columbus and his followers. That was such a contradiction, because children had to be imbued with the British values at the same time they were developing their own identity, who they were, where they came from and what place in society they should occupy. The biggest problem was to face the difference between the British ideal world and the native's own reality, which was regarded as inferior and worthless.

In fact, I was no longer on the same chapter we were studying. I was way ahead, at the end of chapter about Columbus's third voyage. In this chapter, there was a picture of Columbus that took up a whole page, and it was in color - one of only five color pictures in the book. In this picture, Columbus was seated in the bottom of a ship. He was wearing the usual three-quarter trousers and a shirt made of

https://periodicos.unifap.br/index.php/letras

Macapá, v. 9, n. 2, $2^{\circ}$ sem., 2019 
maroon-colored velvet. His hat, which was cocked up on one side of his head, had a gold feather in it, and his black shoes had huge gold buckles. His hands and feet were off into space, looking quite dejected and miserable. The picture had as a title "Columbus in Chains," printed at the bottom of the page. (...) When I next saw the picture of Columbus sitting there all locked up in his chains, I wrote under it the words “The Great Man Can No Longer Just Get Up and Go.” (KINCAID, 1985, p.77)

It is easy to understand Annie's act of rebellion against Columbus and against a system which does not recognize her as an individual with her own history, culture and values. Columbus' incident at her school seems to be a small detail, but the reader should have a very careful look at it. Christopher Columbus is used in the book as a symbol of the contradiction of a colonial educational system. On one hand, he is considered as a great hero, an exceptional navigator and an explorer, a discoverer and a founder of the New World. On the other hand, from the Antiguan's perspectives he is a villain, guilty for the enslavement of their ancestors, the exterminator of the natives' history and culture. From this point of view, he couldn't be the discoverer of the New world, once it had already been discovered by the natives who had their own history and culture.

That is why this question puzzles Annie and she does not know which side they belong to the masters' or the slaves' because now they have to glorify Columbus and to celebrate the Queen's birthday even the descendants of slaves who are well aware of their origins as victims of their histories. Annie, on the other hand, is happy to see Columbus who is usually pictured as triumphant, but in the book he is humble and brought down. For her it seems like a punishment for as a result of the extermination of the natives and enslavement of her ancestors.

On the other hand, the lost paradise also represents the real home of the slaves' descendants, a place they know it is impossible to come back and where their existence was right and natural, consonant with the beauty of creation, with the creator and all creatures. However, their paradise suddenly became a hell, the relation between creator and creatures turned into colonizers and colonized. In such a hell, they will never be a real person as they used to be and in this hell they have been punished for a crime they did not know they have committed, maybe they have been punished for the very crime of being born as people in a place of eternal loss, for unknown reasons. But it cannot be forgotten that they live in a racist colonial society and in such a case, the reasons are very well known.

About this issue, D. Mistron in Understanding Jamaica Kincaid's Annie John gives the reader a comprehensible context about Columbus trips and the reasons why he was in chains and had to come back to Spain in such a humiliating way. She explains that he arrived in the Caribbean islands on October 12, 1492. When he first met the local natives, who he named Indians because, erroneously, he thought he had reached the East Indies. He built a settlement in the island with the help of an Indian leader and returned triumphantly to Spain. There, he received orders to set up for his second voyage with the clear instructions to convert the natives to Christianity, to establish a trading colony and to determine if Cuba was the Eastern portion of Asia. When he sailed off to Cuba, he left his brother Diego in charge of the island and two other men Pedro Margarit and Alonso de Hojeda. However, these two men ruined the relations with the natives; Margarit captured boys as slaves' labours and girls as sex slaves for his men. Diego was against his move and when Columbus came back, he found all this troublesome situation to solve. Margarit, on the other hand, returned to Spain to give the Queen a negative report on Columbus' actions.

Besides that, Columbus was having problems to find gold and to compensate he enslaved the natives, from which five hundred who were shipped to Spain, two hundred died at the sea and others were sold in Seville. The ones who remained tried to escape, but the Spaniards fought battles against the natives to consolidate their control over them. After the natives were pacified, they instituted a gold tribute, so that the natives had to find gold to them within three months, the ones who refused had their hands cut off and had their lives made miserable. Many tried to refuse to crop for the Spaniard, but those received supply from abroad and the natives ended up 
starving. Many escaped to the mountains, but they were chased by big dogs and then killed and others committed suicide. At the end it has been estimated that the native population declined by one third to one half between 1494 and 1496 and within fifty years the natives disappeared.

By 1498 the negative reports against Columbus had infected the Queen, who sent

Francisco de Bobadilha to investigate the situation, giving him full authority even over Columbus. When Bobadilha arrived he saw the terrible condition with seven executed Spaniard, as a result he arrested Diego and Columbus, had them put in chains and shipped home to Spain. Columbus successfully defended himself to the Queen, but the monarchs had ended his power and political authority by appointing Nicolas de Ovando, as governor of the islands. Jamaica Kincaid has also published a critical book about him called Ovando.

In the twentieth century, with the decline of European colonialism, the negative aspects of Columbus as hero and explorer have been expressed. Many descendants of the original native tribes, most of them from Dominica, like Annie's mother, and the descendants of slaves like Annie have been strongly opposed to the glorification of Columbus.

David E. Stannard, in American Holocaust: the conquest of the New World, says that Columbus' deeds in the islands he had "discovered" resulted in a complete holocaust. The island was effectively desolated; nearly eight million people had been killed by violence, disease and despair. For him, what happened in the islands was the equivalent of more than fifty Hiroshimas and that was only the beginning of a long process of devastation.

He goes furthers in saying that the destruction of the Indians in America was the most massive act of genocide in the history of the world. Scholarly estimates of the size of the postColumbian holocaust have climbed sharply in recent decades. However, academic discussions have reduced the devastated indigenous peoples and their cultures to statistical calculations in recondite demographic analyses. He reminds the reader of an important question for the future, but in this case it is not "can it happen again?", rather it is "can it be stopped? For the genocide in the Americas and in other places where the world's indigenous peoples survive, has never really ceased. From the forest of Brazil and Paraguay and elsewhere in South and Central America, where direct government violence still slaughters thousands of Indian people to the reservations and urban slums of North America, where more sophisticated indirect government violence has precisely the same effect. He says that other reminders surround us and we do not need to go further to see the signals and consequences of such devastation. The same aboriginal people which appear on the propaganda of the Olympic Games, might it be in Australia, Canada or Brazil, are the same people we see homeless in the streets and that is why it is important to hear Annie's echo of rebellion against the facts that represent not only a "Paradise Lost", but more than that they represent the loss and the holocaust of uncountable people who had an important task for the western civilization, but they were silenced, they had their hands and ears cut off and at the end they were thrown to the dogs.

\section{Final Considerations}

In Culture and Imperialism, Said says that the main battle in imperialism is over land, of course, but when it came to who owned the land who had the right to settle and work on it, who kept it going, who won it back and who now plans its future - these issues were reflected, contested and even for a time decided in narrative. The power to narrate, or to block other narratives from forming and emerging is very important to culture and imperialism. What Said thinks striking in these discourses are the rhetorical figures one keeps encountering in their notions about bringing civilization to primitive or barbaric peoples, the disturbingly familiar ideas about flogging or death or extended punishment seeing required when they misbehaved or become rebellious, because they mainly understood force or violence best and for that reason deserved to be

https://periodicos.unifap.br/index.php/letras

Macapá, v. 9, n. 2, $2^{\circ}$ sem., 2019 
the rulers. According to him, authors are very much in the history of their societies, shaping and being shaped by that history and their social experience in different measure. Since culture and aesthetic forms derive from historical experience.

In order to build her own identity, she could not find a better way, but leaving both her mother and her motherland. She has to come to terms with her identity and the imposed educational system she was brought on. In most of her novels, Jamaica Kincaid makes use of the literary canon to subvert the discourse and inscribe her own voice in the present discourse on postcolonial literature, in dealing with questions of mother and motherland, powerful and powerless, colonized and colonizers. By doing so, it can be noticed that Kincaid's fiction writes a historical revision, a feminist one, because it is written on a woman's point of view trying to shake the values of the patriarchal society.

\section{References}

BHABHA, Homi. The Location of Culture. London: Routledge, 1994.

BOUSON, J. Brooks. Jamaica Kincaid: Writing memory, writing back to the mother. New York: State University of New York, 2005.

KINCAID, Jamaica. Annie John. New York: Farrar, Straus and Giroux, 1985. . "Jamaica Kincaid's New York”. Rolling Stones. 06 Out. 1977.

MILTON, John. Paradise Lost. London: Penguin Books, 2000.

MISTRON, Deborah. Understanding Jamaica Kincaid's Annie John. London: Greenwood Press, 1999. Callaloo, 13:2 (1990). p.320.

MURDOCH, H. Adlai. Severing the (M)other connection: the representation of cultural identity in Jamaica Kincaid's Annie John. Callaloo, 13:2 (1990). p.320.

SAID, Edward W. Culture and Imperialism. New York: Alfred A. Knopf, 1993.

SIMMONS, Diane. Jamaica Kincaid. New York: Twayne, 1994.

STANNARD, David E. American Holocaust: the conquest of the New World. New York: Oxford University Press, 1993.

TIFFIN, Helen. Cold Hearts and (Foreign) Tongues: Recitation and the Reclamation of the Female Body in the Works of Erna Brodber and Jamaica Kincaid. Callaloo, 16:4 (1993). p.909-921.

VALENS, Keja. Obvious and Ordinary: Desire between girls in Jamaica Kincaid's Annie. Journal of Women Studies. 25:2. (2004). p. 124-149.

Envio: 30/08/2019

Aceite: 10/10/2019 